\title{
Indonesian Local Wisdom: State of the Art
}

\author{
Rohmani Nur Indah ${ }^{1, *}$ Galuh Nur Rohmah ${ }^{2}$
}

\author{
${ }^{1}$ Universitas Islam Negeri Maulana Malik Ibrahim Malang, Indonesia \\ ${ }^{2}$ Universitas Islam Negeri Maulana Malik Ibrahim Malang, Indonesia \\ *Corresponding author. Email: indah@bsi.uin-malang.ac.id
}

\begin{abstract}
This paper explores the dynamics of research on Indonesia's local wisdom from the perspective of the nation's researchers. Local wisdom is a magnet for moral learning, especially what cannot be avoided, namely its potential role for character-building education to prepare better future generations. The data collection involved a scientific research method of identifying research articles from the open-access journal. The template was analyzed to portray the literature mapping on Indonesian local wisdom from the open-access journal articles in the last five years. The dimension to identify covered the scope, rationale, method, and implication. In general, the scope of research in local wisdom in Indonesia covers four dominant study areas, namely education, language teaching, culture, and humanities. The rationales are based on Indonesia's cultural heritage and diversity, the need to prepare a better generation of Indonesia, facing the social issues in the global world, and the current use of local languages. Indonesian local wisdom studies use the literature review, single-site case study, descriptive qualitative analysis, $R \& D$ research, content analysis, action research, and survey research. The implications were addressed to the area of pedagogy, the development of teaching materials, and the field of anthropology. However, few implications are found in covering the fields of sociolinguistics, pragmatics, tourism, design, and social science. Further studies on the elements of Indonesian local wisdom studies and their application to any field of studies would be worth exploring.
\end{abstract}

Keywords: Local wisdom, cultural heritage, character building.

\section{INTRODUCTION}

Local wisdom is part of the cultural heritage of a nation. In recent years, the integration of local wisdom has become a part of character-building education, becoming increasingly prominent. As a result, there has been an explosive wave of innovation in research on local wisdom. Local wisdom is also often considered to have various functions that can be applied in various contexts. One of them is as a form of adaptability to culture in social discourse which then creates cultural diversity. In addition, local wisdom is also a social institution that characterizes ethics and cultural values that develop in society. Therefore, it is not surprising that the dynamics of local wisdom has become one of the special concerns of world researchers. For this reason, this research specifically focuses on developing research on local wisdom to see the future potential in reaching a broader orientation on research related to local wisdom in Indonesia and several other countries.
Local wisdom is a magnet for moral learning, especially what cannot be avoided, namely its potential role for character-building education to prepare better future generations [1][2]. Especially if you look at the current conditions where literacy skills in Indonesia are still quite apprehensive [3], efforts to improve and strengthen the quality of students in Indonesia as a digital generation become a necessity in itself [4]. Moreover, if this local wisdom is introduced to the generation of this digital era early on, of course, the results are believed to be better [5]. Thus, it is clear that local wisdom is one of the important issues that needs to be explored further considering its huge role, especially for characterbuilding education.

So far, what has been a concern is why local wisdom needs to be raised and emphasized as a research focus because of the shift or dynamics of information development in the global era, which is feared to undermine cultural heritage values [6]. However, in this case, what should not be forgotten is 
the richness of Indonesian cultural treasures, which is a concern for world researchers. For this reason, it is still necessary to explore further how the dynamics of the latest research on local wisdom in Indonesia areas studied by researchers, observers, and research activists in Indonesia to find out the pattern of current studies on local wisdom. In this way, it would also identify how the pattern of development of studies in the field of local wisdom shows what issues are a concern in today's global context. On the other hand, local wisdom issues that have been less attractive in the last decade will also be known.

It's a shame if the wealth of local wisdom in Indonesia becomes the main topic of international research but becomes a topic that is less attractive to Indonesian researchers themselves. For this reason, a study that explicitly explores the dynamics of research on Indonesia's local wisdom is needed from the perspective of the nation's researchers. Of course, the results of the analysis and research recommendations will be different than if the issue of local wisdom is viewed from the perspective of international researchers. However, because good research provides internalized experience for the researcher himself, in this case, the strength of Indonesian researchers in elevating cultural heritage in the form of local wisdom is the starting point in this literature study. Therefore, in the long term, the findings of Indonesian researchers are expected to be in line with foreign research in terms of quantity and quality when exploring the issue of local wisdom.

\section{METHOD}

The data collection involved a scientific method of identifying research articles from open-access journals [7]. This process was done in August 2021, taking four stages. First was searching referred articles through the platform of Google Scholar with the keywords Indonesian local wisdom resulting in 65,000 titles. The second stage was limited to the current five years that were 17,400 titles. Then, after the search was limited to reviewing open-access articles, the number of the paper became 491. The last stage was data reduction to choose only the articles written by Indonesian authors that have been cited by other studies, which resulted in 27 titles.

The next phase was template analysis to portray the literature mapping on Indonesian local wisdom from the open-access journal articles in the last five years. The dimension to identify covered the scope, rationale, method, and implication. The identification included the area of analysis the study addressed in terms of scope. The rationale involved the motive of the study or the researcher's concern to conduct the analysis. On its method, the identification deals with the type of research design. Finally, the analysis was also done on the research implication on how the finding of the study yield contributions.

\section{THE STATE OF THE ART OF INDONESIAN LOCAL WISDOM}

\subsection{Scope of Indonesian Local Wisdom Studies}

In general, the scope of research in the topic of local wisdom in Indonesia covers four study areas, namely education (40\%), language teaching (33\%), culture (15\%), and humanities (12\%). First, the most common is in the education area. The level of education, which is the starting point of research on Indonesian local wisdom, ranges from primary to tertiary education. Thus, it is clear that local wisdom continues to be developed in relation to the transmission of essential cultural values passed down from one generation to the next through education.

In research involving the primary education level, the emphasis is on the importance of understanding and loving the Indonesian nation's multicultural culture, which is rich in local wisdom [8]. In research with a target level of junior high school education, the findings recommend the involvement of the local potential that has a wealth of local wisdom [1]. As for studies targeting senior high school level education, focus on instilling local wisdom through school culture [9]. At the university level, local wisdom research involves students' perceptions of their awareness of local wisdom [10] and explores each region's potential with the uniqueness and richness of local wisdom [11][12]. This finding shows that local wisdom has adaptive characteristics so that it can be transformed as cultural values that can be taught not only in basic education but also continuously up to tertiary education level.

Apart from that level, the study of local wisdom also targets general education, for example, to raise community awareness about their local culture. Some of the local wisdoms raised are from Javanese culture [13], Sundanese [14], South Sumatra [3], West Kalimantan [2], and South Sulawesi [15]. In each region, research recommendations lead to people's awareness of the potential of the region but are also involved in the preservation of existing local wisdom. 
The second scope of research in language learning discusses the implications of local wisdom research toward language learning in Bahasa Indonesia, English language, and local language. Local wisdom is expected to become an effective content in Indonesian language learning at the primary education level [16] and become part of Indonesian language learning materials at universities [17] [18]. In addition, local wisdom must also be considered to integrate digital learning [4] and virtual communication [19] in Indonesia. The reason that emerged regarding the link between local wisdom and language learning is the authenticity of the language learning materials. Thus, local wisdombased materials have the potential to be further developed to improve the quality of language learning.

In the context of English as foreign language learning, the materials containing local wisdom are seen as beneficial to be applied at all levels of language learning [20], as well as being an essential part of learning materials that can support cultural preservation [3]. As for learning local languages, local wisdom has strong potential to be integrated as learning materials of Madurese language [21] and Sundanese language learning at the elementary school level [5]. Local wisdom is appointed as material in foreign language learning to re-attach the learner's cultural identity. This is because foreign language learning cannot be separated from cross cultural understanding. Therefore, learners must understand deeply their own culture before developing an understanding of foreign cultures.

In the third position, namely local wisdom studies in the cultural area, the area of cultural studies raised is also various ranging from Asian context to local tradition. For example, the Asian local wisdom is reflected in the greetings that differ in many regions [22]. In the national context, discussing local wisdom is also related to the issue of cross-cultural management [6]. The local wisdom derived from local culture covers Javanese tradition and cultural heritage studies. One tradition that contains local wisdom is grave rituals [23] and philology studies in ancient Javanese manuscripts [24]. Thus, it can be concluded that the dynamics of the study of local wisdom is not only centred on regional circles or localities, but also extends to the world region.

In humanities, research that discusses local wisdom in Indonesia looks at arts and social issues. For example, in performing arts, regional works in Java are full of local wisdom [25]. In addition, the interpretation of local wisdom also influences the development of art in the world of visual design [26]. As for the social field, local wisdom is also one of the considerations in deciding the strategy for corruption eradication [27]. From the two perspectives, art and social context, it appears that the preservation of local wisdom is a special concern, especially in responding to the ever-evolving issue of humanities.

\subsection{Rationale of Indonesian Local Wisdom Studies}

Several vital aspects become the background of the research that strengthens the researchers' argument as a rationale of the studies. The concerns are the cultural heritage and diversity of Indonesia (43\%), the need to prepare a better generation of Indonesia (37\%), facing the social issues in the global world (12\%), and the current use of local languages $(8 \%)$. From these various aspects, Indonesian local wisdom researchers offer the implementation of local wisdom according to their respective contexts.

The introduction of the research, which contains an elaboration of cultural diversity, considers the need for paying more attention to local wisdom in the context of multicultural education [8]. It is then integrated into teaching materials since primary education [16] and in Indonesian language learning [17] and English as a foreign language learning [3][20]. In addition, cultural heritage is also considered essential to be integrated into both available teaching materials [18] and vocational teaching in the tourism sector [11]. Indonesian cultural diversity and heritage as values that are relevant to cultural preservation become the rationale for the study of local wisdom in the context of ethnic culture [15], universal regional culture [22], and ancient cultures that need to be revitalized [24]. As an inference from the rationale, it appears that the researchers are reminding the reader about the richness of Indonesian cultural diversity which is abundant in local wisdom. Thus, researchers seek to remind the need to explore the advantages of each local wisdom.

The second aspect is a rationale of Indonesian local wisdom studies, namely the thought of concerns about the quality of the generation that needs to be prepared to meet the nation's better future. Adolescents as the young generation need an internalized understanding of local wisdom [1]. It also involves cultural awareness to balance their digital literacy [4], so that local wisdom needs to be integrated into course design [10]. The need to prepare a quality generation requires an understanding of local wisdom through project-based 
learning method [12], and being developed to support the preservation of local traditions full of moral values [23]. In addition, the awareness of local culture from Sabang to Merauke is also needed [2][3][9][14]. From the explanation of the rationale on the quality of the new generation, it appears that researchers want a better quality of generation in preserving local wisdom values.

The rationale concerning the need to face the complexities of the global world deals with various social issues [19]. In addition, it is also linked with corruption eradication efforts [27]. In a more specific context, the awareness to maintain local wisdom is also presented in the design industry [26]. Meanwhile, the rationale that raises concerns about reducing local language use in the current years is also a severe issue [5]. One of them is using the Madurese language, which needs to be intensified to support the preservation of local wisdom [21]. In this case, the researchers recommend the need to preserve the cultural values contained in local wisdom as a cultural filter so as not to be eroded by global influences.

\subsection{Design of Indonesian Local Wisdom Studies}

Concerning the method used in Indonesian local wisdom studies, the data show seven types of research design, literature review (28\%), single-site case study (22\%), descriptive qualitative analysis (22\%), R\&D research, content analysis (12\%), action research $(4 \%)$, and survey research $(4 \%)$. Studies on the scope of local wisdom education are more varied in the research design. Whereas the studies on local wisdom in the area of humanities dominantly use descriptive analysis and literature review as the research design.

The literature review has become the prima donna in research design in language teaching, namely in studying local wisdom discourse in communication [19] and developing digital literacy [18]. In addition, several empirical bases on local wisdom are also used to support the argumentation of findings in research on teaching the English language [20], teaching Sundanese language [5], and teaching Madurese local language [21]. Finally, the literature review is also a research design in discussing educational philosophy that integrates local wisdom [13] and discusses cultural heritage discourse that contains local wisdom values to be studied at the primary education level [8]. By using a literature review design, these researchers expect a comprehensive and systematic review on the issue of local wisdom to have strong arguments so that it can become the basis for sustainable research.

In research in the field of education, a single-site case study is seen as a representative research design, namely those that propose school programs based on local wisdom [9], South Sumatran culture as a teaching resource [3], preservation of Toraja culture which is full of local wisdom to be used as educational materials [15], and the rich culture of West Java as learning points [14]. In addition to education, the case study is also a research design in culture analysis, namely in the tradition of people who carry out grave rituals [23]. Single-site case study is the choice of researchers in the field of local wisdom to demonstrate the authenticity of the research subject selection in order to achieve powerful findings.

In local wisdom research, descriptive analysis is preferred for educational research design [2] 10]. In addition, this design is also used in studies in the fields of culture [22], language teaching [3], and humanities [25][26]. By describing the phenomenon of local wisdom inferred from the research site, the findings become more explorative to elaborate the issue more comprehensively.

In Indonesian local wisdom research that looks at old documents or ancient manuscripts, the choice is to use a content analysis design [24]. As for another field, namely language teaching to analyze teaching materials suitable for Indonesian language courses [16][18]. This design represents the local wisdom context implied from work analyzed accurately.

Not many studies use the Research and Development design. Only two were found: Indonesian language teaching based on Makassar local wisdom [17] and local wisdom teaching with a project-based learning model [12]. Likewise, only one study used an action research design based on local wisdom at the junior high school level [1]. Finally, one research utilized a survey method in management research based on local wisdom [6].

\subsection{Implications of Indonesian Local Wisdom Studies}

Findings from research on Indonesian local wisdom results in several implications which practically concern pedagogical contributions (42\%), for the development of teaching materials (30\%), and implications for the field of anthropology (8\%). Few implications are found in covering the fields of 
sociolinguistics, pragmatics, tourism, design, and social science. The implications of each local wisdom research are definite to make sure that it attains to particular parties to follow up the result of the studies.

Research on Indonesian local wisdom in education has full implications in the form of pedagogical contributions. Among them are proposing local wisdom values to construct the theory of Indonesian philosophy of education [13], and recommendations for the integration of local culture as moral teaching for youth based on local wisdom [2][9][11][15]. In addition, local wisdom values are also recommended as an inseparable part of teaching at the primary education level [8]. They also become one of the elements of education at the higher education level [10].

The dominant implication is in the form of a recommendation to use materials containing local wisdom that has been tested as a learning model at the junior high school level [1]. Generally, the implications of this teaching resources model appear in the results of local wisdom research in the field of language teaching, namely the Indonesian course [4][17] and Indonesian language materials at the primary education level [16]. In addition, it is also part of the Sundanese regional language teaching resource [5], and as teaching material for reading Madurese works [21]. Even local wisdom is highly recommended for reading material in teaching English as a foreign language [3][20].

In the field of cultural studies, research that examines local wisdom contributes to the development of research in the field of anthropology and sociology, namely those that use an ethnographic approach [23] and a cross-cultural management survey approach based on local wisdom [6]. In other fields, the implications of the study of local wisdom in Indonesia put its target on the field of sociolinguistics [22], and the implications of the scope of pragmatics [19]. Meanwhile, there are also implications in the field of tourism [11], the scope of visual communication [26], and the area of social science [27].

\section{CONCLUSION}

The study mapped the state of the art of Indonesian local wisdom into four areas. The areas cover the scope of Indonesian local wisdom studies, rationale of Indonesian local wisdom, design of Indonesian local wisdom, and implications of Indonesian local wisdom. Revealing the areas becomes a very significant point of departure to explore Indonesian local wisdom studies. It also deepens the body of knowledge of the related field of study to be a more justified point of view. However, this state of the art is not free from limitations. It still needs more areas to capture. Further studies exploring the elements of Indonesian local wisdom studies and their application to any field of study would be worth investigating.

\section{REFERENCES}

[1] S. Bahri, L. Kusumawati, \& L. Nuraini. STEAM education based on local wisdom of coffee plantation in jember to improve the competitiveness at $21 \mathrm{st}$ century. Pancaran Pendidikan vol. 6.3, 2017.

[2] H. Darmadi. Educational management based on local wisdom (descriptive-analytical studies of culture of local wisdom in West Kalimantan). Journal of Education, Teaching and Learning vol. 3.1, 2018, pp. 135-145.

[3] I. Sari \& H. M. Z. Amrul. Perception of English Learning Based on Local Wisdom for Junior High School Students in Desa Kolam Deli Serdang District North Sumatera Indonesia. Britain International of Linguistics Arts and Education (BIoLAE) Journal vol. 3.1, 2021, pp. 57-62.

[4] R. T. Manurung. Digital Literacy Based on Local Wisdom in Language Learning. KaPIN Conference. 2021.

[5] D. Damayanti \& B. Nurgiyantoro. Local Wisdom as Learning Materials: Character Educational Values of Sundanese Papua. EDULEARN: Journal of Education and Learning vol. 12.4, 2018, pp. 676-684.

[6] A. Y. Mendo. Local Wisdom-Based CrossCultural Management. Journal of International Conference Proceedings (JICP). vol. 2.1, 2019.

[7] A. Fink. Conducting research literature reviews: From the internet to paper. Sage publications, 2019.

[8] A. F. Noor \& S. Sugito. Multicultural Education Based in Local Wisdom of Indonesia for Elementary Schools in the 21st Century. Journal of International Social Studies vol. 9.2, 2019, pp. 94-106. 
[9] S. Madya \& I. Ishartiwi. Instilling character values through a local wisdom-based school culture: An Indonesian case study. Character Education for 21st Century Global Citizens. Routledge, 2018, pp. 371-380.

[10] F. D. N. Pamenang. Local wisdom in learning as an effort to increase cultural knowledge: Students' perception as prospective teachers. International Journal of Indonesian Education and Teaching (IJIET) vol. 5.1, 2021, pp. 93101.

[11] S. Komariah \& F. N. Asyahidda. Local Wisdom as Educational Tourism: A Study from Kampong Dukuh West Java Indonesia. 3rd International Seminar on Tourism (ISOT 2018). Atlantis Press. 2019.

[12] S. Z. Bin-Tahir. Project-Based Learning Model Based on Local Wisdom in Citizenship Education Courses to Prevent Radicalism among Students. 2021.

[13] A. D. Firmanto, \& N. Setiyaningtiyas. Local Wisdom as Integration of the Cosmic and the Metacosmic Perspectives in Indonesian Philosophy of Education. 3rd International Conference on Education and Training (ICET 2017), Advances in Social Science, Education and Humanities Research. Vol. 128, 2017.

[14] P. H. Handayani. Sabilulungan Class Programe in School as an Effort to Integrate Value of Local Wisdom in Education in Bandung, West Java Indonesia. Jurnal Bunga Rampai Usia Emas vol. 3.2, 2017, pp. 34-40.

[15] S. Tarrapa \& I. Junaedi. The Legacy of Local Wisdom Education Models for The Next Generation of Toraja, Indonesia. Technium Soc. Sci. J. vol. 21, 2021, pp. 765-780.

[16] V. U. Pratiwi \& S. Suwandi. Local Wisdom in the Picture Storybook for Elementary School Students in Sukoharjo Regency. Budapest International Research and Critics Institute (BIRCI-Journal): Humanities and Social Sciences vol. 4.1, 2021, pp. 1262-1271

[17] H. Haslinda, M. R. Tang, \& A. S. Syamsuri. The Improvement of Fiction Prose Study as a Teaching Material Based on Makassar Local Wisdom Integrated with Mobile Learning at FKIP Universitas Muhammadiyah Makassar. Journal of Language Teaching and Research vol. 8.5, 2017, pp. 915-921.
[18] M. Fuad, A. Efendi \& U. A. Muhammad. The use of pepaccur local wisdom for Indonesian literary teaching materials. JPI (Jurnal Pendidikan Indonesia) vol. 9.2, 2020, pp. 213223.

[19] I. Ristiani, I. Sharpening the character of local wisdom in virtual communication in indonesia. Utopía y praxis latinoamericana: revista internacional de filosofía iberoamericana y teoría social vol. 2, 2020, pp. 86-97.

[20] A. M. Albantani \& A. Madkur. Think globally, act locally: the strategy of incorporating local wisdom in foreign language teaching in Indonesia. International Journal of Applied Linguistics and English Literature vol. 7.2, 2018, pp. 1-8.

[21] M. H. Effendy et al. Expressing Local Wisdom of Indonesian Madurese through Proverbs. Linguistica Antverpiensia, 2021, pp. 277-291.

[22] A. E. Kadarisman. Local Wisdom with Universal Appeal: Dynamics of Indonesian Culture in Asian Context. KnE Social Sciences, 2017, pp. 8-18.

[23] A. Syakur \&. M. Khoiroh. Local wisdom for civil religious harmony in Indonesia: An ethnographic investigation on Mbah Moni's grave ritual in Babatan village, Wiyung subdistrict, Surabaya city, Jawa Timur province. Kasetsart Journal of Social Sciences vol. 42.3, 2021, pp. 674-681.

[24] A. A. Rofiq et al. Local wisdom on Java manuscript in Banyuwangi: study of Indonesia culture's value. Utopía y Praxis Latinoamericana vol. 24.6, 2019, pp. 78-84.

[25] E. Rahmawati \& H. Putranta. The exploration of local wisdom values of performing arts: An art of Kuda Lumping Sarimpi. Humanities \& Social Sciences Reviews vol. 8.5, 2020, pp. 307-318

[26] N. W. Firmansyah, A. A. Sutrisno, \& A. P. Herwanto. Visual Rhetoric in the Design Process Based on Local Wisdom. KnE Social Sciences, 2021, pp. 227-235.

[27] L. K. Setiadarma. The Role of Local Wisdom as Part of Corruption Eradication Strategy. Asia Pacific Fraud Journal vol. 2.2, 2018, pp. $151-163$ 